$\underline{\mathbf{P}-79}$

\title{
Angiotensin Converting Enzyme Inhibitory Effect of Standardised Extracts from Various Varieties of Ficus Deltoidea
}

\author{
Amirul Ridzuan Abu Bakar, Abdalrahim F.A. Aisha and Zhari Ismail* \\ Department of Pharmaceutical Chemistry, School of Pharmaceutical Sciences, Universiti Sains Malaysia, Minden \\ 11800, Pulau Pinang, Malaysia; E-mail: zhari@usm.my
}

Ficus deltoidea (Moraceae), Mas cotek, is a local medicinal plant which has been used for its health benefits including antioxidant, improving blood circulation and anti-hypertension effects. This study aims to determine the vitexin and isovitexin content in various varieties of $F$. deltoidea, and to study the extract's inhibitory effect on angiotensin converting enzyme (ACE) activity as anti-hypertension marker. Five varieties were studied including $F$. deltoidea var deltoidea, F. deltoidea var. angustifolia, $F$. deltoidea var tranguensis, F. deltoidea var. Telinga Beruk, and F. deltoidea var. Tapak Itik. Five extracts were prepared; water, methanolic, ethanolic, 50\% methanolic and 50\% ethanolic, and ACE inhibitory effect was studied in vitro. Vitexin and isovitexin concentration was in the range $0.001-0.35 \%$ and $0.001-7.025 \%(\mathrm{w} / \mathrm{w})$, respectively. The highest ACE inhibition was obtained from $F$. deltoidea var. Tapak Itik (FD-TI) extracts where the 50\% ethanolic and 50\% methanolic extracts showed the most promising results. A bivariate correlation analysis may indicate existence of relation between vitexin in FD extracts and the ACE inhibition $(\mathrm{r}=0.58)$, whereas the isovitexin results do not show any relationship ( $\mathrm{r}=-0.06)$. The median inhibitory concentration $\left(\mathrm{IC}_{50}\right)$ of the $50 \%$ ethanolic extract of FD-TI was $22 \pm 3.8 \mu \mathrm{g} / \mathrm{ml}$, and that of vitexin and isovitexin was $3.1 \pm 0.5 \mu \mathrm{g} / \mathrm{ml}, 18.6 \pm 1.3 \mu \mathrm{g} / \mathrm{ml}$, respectively. Our results showed the ACE inhibitory effect is partly due to existence of vitexin but not isovitexin, and the $50 \%$ ethanolic extract of the $F$. deltoidea var. Tapak Itik as a possible antihypertension candidate.

Keywords: Vitexin, Isovitexin, Ficus deltoidea, Anti-hypertension. 